\title{
Legal Implication of Law No.11/2020 Concerning Job Creation on Village-Owned Enterprises in Indonesia
}

\author{
Detania Sukarja ${ }^{1}$, Mahmul Siregar ${ }^{2}$ and Tri Murti Lubis ${ }^{3}$ \\ \{detasukarja@usu.ac.id¹,mahmul@usu.ac.id²,trimurti@usu.ac.id³ \\ Universitas Sumatera Utara, Indonesia ${ }^{123}$
}

\begin{abstract}
The enactment of Law No.11/2020 concerning Job Creation ("Job Creation Law") is one of the most controversial issues in Indonesia towards the end of 2020. Village-owned enterprise ("BUM Desa") is one of the aspects that fall within the scope of this new law. This law changes the legal definition of BUM Desa. The change is not only important because it confirms the status of BUM Desa as a legal entity, but it also removes the concept of ownership criteria provisions as stipulated in the 2014 Village Law. The new definition also removes the concept of 'separated wealth' (kekayaan yang dipisahkan), which is the basic characteristic of public companies like BUMN and BUMD, as well as BUM Desa before the enactment of the Job Creation Law. Based on normative legal research, this paper seeks to identify the legal implication of issuance of the Job Creation Law on the legal aspects of BUM Desa. It aims to clarify to what extent the law addresses the various legal problems of BUM Desa and provides legal certainty for related stakeholders. The paper concludes that the Job Creation Law contains a number of provisions that have implications for the legal aspects of BUM Desa, among which: (1) the clarity and confirmation of the status of BUM Desa legal entities as stated in the new operational definition of BUM Desa; (2) The removal of ownership criteria from the operational definition of BUM Desa may open the possibility for BUM Desa to be controlled by private capital and dissolves the concept of village community ownership of BUM Desa; (3)The provisions regarding BUM Desa in the Job Creation Law has not clarified the misconception of BUM Desa as stipulated in the Village Law and the derivative regulations, but instead contains conflicting provisions that may spark further debate and maintain legal uncertainty in BUM Desa management and development. The implementing regulations relating to BUM Desa under the Job Creation Law to await finalization of the draft Law on BUM Desa to ensure consistency.
\end{abstract}

Keywords: omnibus law; village-owned enterprise; village; bumdes

\section{Introduction}

\subsection{The Establishment of Village-Owned Enterprises for Economic Resilience}

The Indonesian government has strategically positioned the village as a major force that is expected to contribute to achieving Indonesia's mission of being sovereign, prosperous and dignified (berdaulat, sejahtera dan bermartabat). One of the 9 priority programs of the Government of President Joko Widodo (also known as "Nawacita") since being elected in 2014 is to develop Indonesia from the periphery by strengthening regions and villages within the framework of a unitary state [1]. The ratification of Law No. 6/2014 concerning Village ("Village Law") is one of the main motors to make this happen. 
The Village Law positions the village as a legal community unit that has the right to autonomy to regulate and manage its own interests [2]. The autonomy that the village has is genuine autonomy, that is, autonomy that is not granted or delegated from the central government or the national government [3]. Through this law, the state recognizes the rights of origin or traditional rights of villages that existed before Indonesia was established.

Village community business and economic development can increase competitiveness which then encourages economic growth. The existence of the village as the lowest regional unit will have a positive impact nationally in facing free market competition [4]. The success of programs such as One Tambun One Product (OTOP) [5] in Thailand or One Village One Commodity (OVOC) [6] in Japan shows that villages have great potential in supporting economic development. In China, the development and success of Township-Village Enterprises (TVE) has become one of the engines driving the country's economic growth. These have inspired one of the government's strategies in "developing Indonesia from the periphery" through the development of Village-Owned Enterprises or Badan Usaha Milik Desa ("BUM Desa") [7].

The development of BUM Desa has continued to be promoted by the government in the past 5 years. A similar concept to the BUM Desa or Village-owned business units actually existed before the issuance of the Village Law. However, the BUM Desa nomenclature has become increasingly strategic because of its important role as a supporter of village economic resilience [8].

BUM Desa is a village-characterized business entity that has both economic and social orientation. The establishment of BUM Desa is in line with the constitutional mandate for the realization of the people's welfare and is within the framework of the concept of a welfare state [9]. BUM Desa can run public service businesses such as village drinking water management, village electricity or food barn, as well as commercial businesses such as rentals (transportation vehicle, tractors, party utensils, building), brokering (acting as marketing agencies for community agricultural and livestock products, handicrafts), trading (such as agricultural commodities for community needs and a wider business scale) or financial business (micro financing).

Based on data released by Lokadata, the number of BUM Desa in 2014 was 1022 units. This number then increased to 50199 units in 2019. Through BUM Desa, it is hoped that each village can optimize existing village assets, advance the village economy, and improve the welfare of the village community [10]. Of the many BUM Desa that have been established in villages all over Indonesia, there are many success stories as well as mishaps. The development of BUM Desa cannot be separated from various challenges. This of course is very diverse because every village is unique with its own characteristics and potential and, therefore, the arising challenges also varies.

From a legal perspective, the success of BUM Desa is also inseparable from various challenges. In the legal system framework initiated by Lawrence M. Friedman, these challenges can be qualified into the aspects of the structure of law, substance of law and legal culture [11]. Challenges in the aspect of the substance of the law include the regulatory framework that has not confirmed the status of BUM Desa legal entities, the unclear basic conception of BUM Desa and governance rules that do not comprehensively contain norms that reflect the principles of good corporate governance.

In the aspect of the structure of law, the main challenge is the capacity of BUM Desa organizers/manager. The capacity problem has also been confirmed by a number of studies that have been carried out, including the results of the study by Anggraeni (2016) [12] and Sukarja, et.al (2019) [13]. BUM Desa were seen to be established and management 
arrangements formed without a strong business feasibility study, but rather for pragmatic purposes, such as obtaining the distribution of the use of the Village Fund. BUM Desa managers generally do not understand the importance of sharing roles and responsibilities in the context of upholding the principles of Good Corporate Governance (GCG).

Challenges in the aspect of legal culture include, among others, the dominant control of Village Head which may affect the managerial autonomy of managers of BUM Desa. Other challenges include the mentality of the Village community that does not support the existence and development of BUM Desa and the moral hazard or opportunistic behavior of a number of BUM Desa managers who use BUM Desa for personal gain, compared to the sustainability of BUM Desa and rural economic progress [14]. These problems are a challenge in itself in drafting and improving regulations on BUM Desa.

\subsection{The Enactment of Law No.10/2020 concerning Job Creation}

The ratification of Law No.11/2020 concerning Job Creation ("Job Creation Law") in November 2020 is one of the legal dynamics that has generated public debate. This law applies the omnibus method, which is the preparation of 1 (one) piece of legislation to revise multiple regulations. Omnibus Law is a method of drafting legislation which is better known in the Common Law legal system.

Black's Law Dictionary defines the omnibus bill as:

(1) a single bill containing various distinct matters, usually drafted in this way to force the executive either to accept all the unrelated minor provisions or to veto the major provisions; (2) a bill that deals with all proposals relating to a particular subject, such as an 'omnibus judgeship bill' covering all proposals for new judgeship or an 'omnibus crime bill' dealing with different subjects such as new crimes and grants to states for crime control.

Although the omnibus law method has previously been applied narrowly in Indonesia [15], the Job Creation Law is the first legislation product that has revised such a large number of laws at the same time. In this case, the Job Creation Law revises around 80 laws, covering around 1200 articles. This law requires the enactment of 52 implementing regulations. The scope of regulation in this Law includes 11 clusters, namely simplification of licensing, investment requirements, employment, land acquisition, ease of doing business, research and innovation support, government administration, imposition of sanctions, empowerment and protection of MSMEs, government investment and projects and economic zones. The Job Creation Law aims to encourage investment which in turn creates more jobs.

The Omnibus Law method is used to overcome the problem of hyper regulation and ineffective policies that affect the investment climate. However, this law also invites debate in the public sphere because it is considered not in line with Law No.12/2011 on the Formation of Legislative Regulations (as amended by Law No. 15/2019). The drafting of this Law took place very quickly, not transparent, and lacking public participation. Apart from the formal aspects of the legislation, the material aspects of the law also invite debate, especially those related to labor rights, environmental protection and land aspects.

In relation to the development of BUM Desa, one of the laws revised is the Village Law. The Job Creation Law contains several articles that revise provisions on BUM Desa. This was greeted in various ways by BUM Desa activists. This paper aims to examine the impact of the application of the Job Creation Law on the legal aspects of the BUM Desa and the extent to which the Job Creation Law addresses problems in the development of BUM Desa. It is prepared based on normative legal research methods, namely legal research which refers to the legal norms contained in statutory regulations. The approach used is the statutory approach (statute approach). 


\section{Discussion}

The Job Creation Law contains a number of regulations that are directly related to BUM Desa which include the scope of business activity, legal entity status and operational definition. The draft regulation on BUM Desa that has been prepared as implementing regulations for the Village Law and the Job Creation Law contains a number of provisions regarding the governance of BUM Desa. In addition, there are also regulations that indirectly intersect with BUM Desa, namely the revision of Law No.40/2007 on Limited Companies ("Limited Company Law") regarding the requirements for establishment. The government has also drafted a government regulation for BUM Desa as part of the implementing regulations of the Job Creation Law (accessible for the public at https://uu-ciptakerja.go.id).

Although this regulation has not yet been legally enacted, it provides an overview of the future direction and scope of the BUM Desa regulation in the framework of the Job Creation Law. The implications of the application of the Job Creation Law on the legal aspects of BUM Desa will be further elaborated as follows:

\subsection{The scope of the BUM Desa Line of Business}

Article 53 (which amends Law No. 22 of 2009 on Road Transportation Traffic) and Article 55 (which amends Law No. 17 of 2019 concerning Water Resources) of the Job Creation Law strengthens the legal basis for BUM Desa to manage public transportation terminals and water resources in the village. Many BUM Desa have so far managed water resources in the village to meet the drinking water needs of the village community. Normatively, the village community has the right to manage natural resources at the village scale to realize the welfare of the village community which may be carried out by the BUM Desa.

However, based on the results of Surono's study (2017) the implementation has not been optimal because, among other things, there is still a lack of understanding of village government officials about village authority in managing village-scale natural resources and there are overlapping laws and regulations related to village authority in several technical regulations [16].

\subsection{The Legal Entity Status of BUM Desa}

The legality of a business entity is one of the most important aspects in running a business because legality is an identity that gives approval and recognition from the community [17]. The legality of the establishment of BUM Desa greatly affects the prospects for growth and development. Legal aspects of business entities generally include, among others, the legal basis of establishment, legal aspects of licensing, legal entity status and legal relationships with third parties.

The clarity of the status of the BUM Desa legal entity provides a legal personality for BUM Desa to a run business. The status of a legal entity underlies the existence of BUM Desa and recognition from third parties in establishing legal relationships with third parties, especially BUM Desa business partners. The status of a BUM Desa legal entity also clarifies the autonomy of its management and its separation as a legal subject from the village as a legal entity of its own. This is important to reinforce the lines of financial responsibility for each entity. In the context of procedural law, the status of a legal entity clarifies the legal position of BUM Desa to sue or be sued in court.

BUM Desa are established based on Village Regulations ("Perdes") and based on this characteristic theoretically BUM Desa are a public legal entity. However, the Village Law and 
its implementing regulations do not explicitly mention the status of BUM Desa as a legal entity. This problem has created doubt about the legal personality of BUM Desa in its business activities, including its capacity to become shareholders of the business units it establishes.

The Job Creation Law in this case provides a new operational definition for BUM Desa that clarifies its position as a legal entity. The new operational definition emphasizes that BUM Desa is a legal entity (compared to the previous definition that only described BUM Desa as a business entity). To obtain legal entity status, however, the regulation draft on BUM Desa requires the village governments to register the BUM Desa to the village information system that will be integrated with the legal entity administration system at the Ministry of Law and Human Rights. The Minister of Law and Human Rights will then issue a BUM Desa registration certificate, where this will be further regulated through a regulation of the Minister of Law and Human Rights.

In practice, the effective implementation of this system will have an impact on determining the legal personality of BUM Desa. The system previously used by the Ministry of Law and Human Rights did not acknowledge BUM Desa as a form of business entity.

\subsection{The Legal Definition of BUM Desa}

The Job Creation Law provides a new legal limit or definition for BUM Desa. Comparison of these definitions can be seen in the following table:

Table 1. Comparison of BUM Desa definitions in Village Law and Job Creation Law

\begin{tabular}{l} 
Village Law \\
\hline "Business entities that all or "Established by villages and/or \\
most of the capital is owned by together with villages to manage \\
the Village through direct businesses, utilize assets, develop \\
participation derived from the investment and productivity, provide \\
wealth of the village are services, and/or provide other types \\
separated to manage assets, of businesses for the greatest welfare \\
services, and other businesses of the village community."" \\
for the amount of welfare of the \\
village community"
\end{tabular}

In the previous definition stipulated in the Village Law and its implementing regulations, there is still the phrase "separated wealth", which means assets or assets that are allocated and removed from the state / regional / village budget as a legal entity to be transferred and included as capital in a business entity. The concept of "separated wealth" is characteristic of similar business entities such as State-Owned Enterprises ("BUMN") and Region-Owned Enterprises ("BUMD") in Indonesia. The operational definition of BUM Desa in the Job Creation Law, however, has removed the phrase "wholly or largely owned by the Village through direct participation originating from separated Village assets ".

Government Regulation No. 43/ 2014 as the implementing regulation of Village Law (amended by Government Regulation No. 47/2015) held that BUM Desa assets consist of village capital participation and village community capital participation. Regulation of the Minister of Villages, Development of Disadvantaged Areas and Transmigration No. 4 /2015 on the Establishment, Management, Governance and Liquidation of BUM Desa opens opportunities for private capital participation in BUM Desa (Article 18).

However, this participation cannot be done directly, but through the Village Budget ("APB Desa") mechanism. In other words, private investors do not have a direct legal relationship with the BUM Desa, but through the village. Whereas for village community capital participation is capital that comes from community savings. However, based on the BUM Desa draft regulation as part of implementing regulations for the Job Creation Law, 
village community capital participation is no longer limited to the form of community savings (for BUM Desa which is engaged in savings and loans), but can also come from other sources.

In Article 41 of the regulation draft, village community equity participation can come from legal entities, non-legal entities, individuals, a combination of people from the local village and/or villages. Capital in this case can be in the form of money and / or goods, whether land and buildings or not land and buildings. Unlike the current regulations which stipulate that private capital must be carried out through the APB Desa mechanism, Article 43 of the regulation draft also states that such capital participation can be channeled directly to BUM Desa. Thus, conceptually BUM Desa can also be "owned" by private parties other than the village community.

The regulatory draft confirms the writer's understanding that changing the definition and legal boundaries of BUM Desa opens opportunities for private ownership within the BUM Desa body. This of course will obscure the legal status of BUM Desa as a public legal entity and the basic conception of BUM Desa as a village-characterized business entity that is not the same as limited companies and cooperatives. With regard to loans, the current law contains a broad stipulation that a BUM Desa is allowed to obtain loan as source of funding to further develop its business. The regulation provides no further explanation on the sources of loan and limitations.

The regulation draft on BUM Desa, however, expands and elaborates on this this further by stipulating that BUM Desa may obtain capital from loans with due observance of the principles of transparency, accountability, efficiency and effectiveness, as well as prudence and with the approval of advisors or village meetings. Loans can be submitted to financial institutions (both banking and non-banking), central government, regional governments, and other domestic sources of funds provided that:

a. loans are used for business development and/or establishment of Village-Owned Enterprise Units;

b. the repayment period of the principal loan, interest, and other costs does not exceed the remaining term of the manager/director;

c. BUM Desa has a sound financial report for at least 2 (two) consecutive years; and

d. Taking loan does not result in a change in the proportion of capital ownership (that is, the type of loan that can be converted into capital participation if BUM Desa is unable to fulfill the obligations arising from the loan).

On one hand, this is positive because it provides a clearer and stronger legal basis for funding options for BUM Desa to expand and develop business scale. However, existing studies identify that BUM Desa face various governance issues, especially related to management capacity coupled with business risks. In these circumstances non-refundable loans may in turn burden the village and this is contrary to the spirit of establishing BUM Desa for encourage the independence of the village economy and the realization of the welfare of the village community.

\subsection{Basic Conception of BUM Desa}

A previous study argued that the current legal framework of BUM Desa contains logical inconsistency on the basic conception on BUM Desa. Several stipulations in the implementing regulations of the Village Law assume BUM Desa as private legal entities [18]. The Village Law states that BUM Desa is a business entity unique to villages that is not the same as limited company and cooperatives. This has been re-emphasized in the Job Creation Law. 
BUM Desa has similarities with Indonesian cooperatives because it is managed based on the principles of kinship (kekeluargaan) and mutual cooperation (gotong royong).

However, the remaining features of a BUM Desa is not the same as a cooperative. BUM Desa shares similar characteristics with BUMN and BUMD. Nevertheless, unlike BUMN and BUMD, BUM Desa by concept cannot be corporatized into the form of limited company form. The law provides that BUM Desa may only create business units in limited company forms. The kinship and mutual cooperation nuance embedded into the concept means that it is not to be established in a capitalist management system to profit private entities, but rather for communal interests (village communities' welfare). BUM Desa is more similar to BUMN and BUMD in the form of public corporation because it is not divided into shares (Perum and Perumda).

The comparison between BUM Desa compared to PT and cooperatives can be seen further the following table:

Table 2. Comparisons between BUM Desa, limited company and cooperatives

\begin{tabular}{|c|c|c|c|c|}
\hline No & Criteria & BUM Desa & Limited Company & Cooperatives \\
\hline 1 & Ownership & Owned by village & Owned by shareholders & Owned by members \\
\hline 2 & Establishment & $\begin{array}{l}\text { Established by } \\
\text { Village Regulation } \\
\text { (Peraturan Desa) }\end{array}$ & $\begin{array}{l}\text { Established with } \\
\text { notarial deed followed } \\
\text { by legalization of the } \\
\text { Minister of Law and } \\
\text { Human Rights }\end{array}$ & $\begin{array}{l}\text { Established with } \\
\text { notarial deed } \\
\text { followed by } \\
\text { legalization of the } \\
\text { Minister of Law } \\
\text { and Human Rights }\end{array}$ \\
\hline 3 & Legal status & Public legal entity & Private legal entity & Private legal entity \\
\hline 4 & Characteristic & $\begin{array}{l}\text { No members or } \\
\text { shareholders, } \\
\text { unique to villages }\end{array}$ & Shareholding & $\begin{array}{l}\text { Based on } \\
\text { membership }\end{array}$ \\
\hline 5 & $\begin{array}{l}\text { Source of } \\
\text { equity }\end{array}$ & $\begin{array}{l}\text { Village budget, } \\
\text { community fund }\end{array}$ & $\begin{array}{l}\text { Shareholders (person } \\
\text { or legal entity) }\end{array}$ & $\begin{array}{l}\text { Members } \\
\text { (Person or legal } \\
\text { entity) }\end{array}$ \\
\hline 6 & $\begin{array}{l}\text { Business } \\
\text { orientation }\end{array}$ & $\begin{array}{l}\text { Social and } \\
\text { commercial }\end{array}$ & Commercial & Commercial \\
\hline 7 & Objectives & $\begin{array}{l}\text { Managing Village's } \\
\text { economic potential }\end{array}$ & $\begin{array}{l}\text { Generating profit for } \\
\text { shareholders }\end{array}$ & $\begin{array}{l}\text { Generating profit } \\
\text { for members }\end{array}$ \\
\hline 8 & Founder & Village & $\begin{array}{l}\text { Individual (person or } \\
\text { legal entity) }\end{array}$ & $\begin{array}{l}\text { Individual } \\
\text { (Person or legal } \\
\text { entity) }\end{array}$ \\
\hline 9 & Accountability & $\begin{array}{l}\text { To village } \\
\text { (Musyawarah Desa) }\end{array}$ & $\begin{array}{l}\text { To general } \\
\text { shareholders' meeting }\end{array}$ & $\begin{array}{l}\text { To members } \\
\text { meeting }\end{array}$ \\
\hline
\end{tabular}

The changes outlined in the Job Creation Law have not provided an answer to the vagueness of the basic conception of BUM Desa. This is in line with the argument in the previous section, that private participation or ownership within the BUM Desa body will obscure the character of BUM Desa as a public legal entity and the basic conception of BUM Desa as a village-characterized business entity that is not the same as limited companies and cooperatives.

Moreover, article 109 (2) of the Job Creation Law, which amends Article 7 of the PT Law on the establishment of a PT stipulates that the obligation to establish a PT by 2 (two) or more persons does not apply to: 
a. BUMN, all of whose shares are owned by the state;

b. Regional owned enterprises;

c. Village Owned Enterprises;

d. Companies that manage stock exchanges, clearing and guarantee institutions, depository and settlement institutions, and other institutions in accordance with the Law on Capital Markets; or

e. Companies that meet the criteria for Micro and Small Enterprises.

The article implicitly states that BUM Desa can be established in a limited form. Such interpretation contradicts the explanation of the Village Law which states that BUM Desa is not the same as PT or cooperative, and this is still emphasized in the elucidation of the Job Creation Law. Thus, the Job Creation Law not only does not straighten the BUM Desa concept according to its founding philosophy, but instead provides room for interpretation which further obscures it.

\subsection{Governance Aspect of BUM Desa}

Both the Job Creation Law and the Village Law do not provide any specific stipulations relating to the corporate governance of BUM Desa. However, the draft regulations covering BUM Desa contain many provisions that will affect how BUM Desa are governed. Draft regulations provide for village councils (musyawarah desa), intervillage councils (musyawarah antar desa) along with advisers, managers and supervisers as organs of the BUM Desa.

Whereas, the current law does not identify village councils as organs in the corporate governance structure of BUM Desa but rather views the role of village councils as reviewing performance in an oversight capacity. The approach proposed in draft regulations differs from regulatory framework for BUMN and BUMD in the form of public corporations, where no similar organ is referenced. This potentially could be interpreted as a re-iteration of the government's view that BUM Desa have their own unique character as distinct from other public corporate entities.

\section{Conclusion}

The Job Creation Law contains a number of provisions that have implications for the legal aspects of BUM Desa. One of the main aspects of change is the clarity and confirmation of the status of BUM Desa legal entities as stated in the new operational definition of BUM Desa. The removal of ownership criteria from the operational definition of BUM Desa may open the possibility for BUM Desa to be controlled by private capital and dissolves the concept of village community ownership of BUM Desa. The provisions regarding BUM Desa in the Job Creation Law have not clarified the misconception of BUM Desa as stipulated in the Village Law and the derivative regulations, but instead contains conflicting provisions that may spark further debate and maintain legal uncertainty in BUM Desa management and development.

A draft Law on BUM Desa has been proposed by Dewan Perwakilan Daerah (House of Regional Representatives) and added to the national legislation program, identifying it as a priority for legislative approval. If one of the objectives of the Job Creation Law is to clarify inconsistencies between overlapping regulations, then it would make sense for implementing 
regulations relating to BUM Desa under the Job Creation Law to await finalization of the draft Law on BUM Desa to ensure consistency.

\section{References}

[1] Putra, A.S: Badan Usaha Milik Desa: Spirit Usaha Kolektif Desa. Kementerian Desa, Pembangunan Daerah Tertinggal dan Transmigrasi Republik Indonesia, Jakarta (2015)

[2] Solekhan, M.: Penyelenggaraan Pemerintahan Desa Berbasis Partisipasi Masyarakat. Setara Press, Malang (2014)

[3] Mashab, M. Politik Pemerintahan Desa Di Indonesia. Research Center For Politics and Goverment/PolGov, Yogyakarta (2013)

[4] Harmiati, A.Z.Z. \& Zulhakim, A.Z.: Eksistensi Badan Usaha Milik Desa (BUMDes) Dalam Mengembangkan Usaha Dan Ekonomi Masyarakat Desa yang Berdaya Saing di Era Masyarakat Ekonomi ASEAN. http://setnas-asean.id/site/uploads/document/journals/file/59b0f03a8a119-14cluster- ekonomi-unihaz.pdf (2017)

[5] Pasaribu, S. M.: Developing of Small and Medium Enterprises For Poverty Alleviation In Indonesia: Lesson Learned From Otop Program in Thailand. Analisis Kebijakan Pertanian. Vol.5, No.1 , pp.53-71. (2007)

[6] Tambunan, M. \& Ubaidillah, (2003). Pasar Global, Apakah Ancaman atau Tantangan Bagi UKM ?, dalam Ekonomi Kerakyatan dalam Kancah Globalisasi. Kementerian Negara Koperasi dan Usaha Kecil dan Menengah. Jakarta. (2003)

[7] Putra, op.cit, hal.9.

[8] Widiastuti, H., Putra, M.P., Utami, E.R., \& Suryanto, R: Menakar tata kelola badan usaha milik desa di Indonesia. Jurnal Ekonomi dan Bisnis. Vol. 22, No. 2. pp.257-288 (2019)

[9] Suartini, Safa'at, R., Permadi, I. \& Istislam: Comparison of Village-Owned Enterprises in Indonesia and Township and Village Enterprises in China. Journal of Law, Policy and Globalization. Vol.91. pp.174 (2019).

[10] Law No.6/2014 concerning Village, Elucidation of Article 87 (1)

[11] Friedman, L. M: The Legal System: A Social Science Perspective. Russel Sage Foundation, New York (1975)

[12] Anggraeni, M.R.R.S: Peranan Badan Usaha Milik Desa (BUMDes) pada Kesejahteraan Masyarakat Pedesaan: Studi pada BUMDes di Gunung Kidul Yogyakarta. Modus. Vol.28, No.2. p.155-167 (2016)

[13] Sukarja, D., Siregar, M., \& Lubis, T.M.: The Regulatory Framework of Village-Owned Enterprise in Indonesia: Does it Conform with Good Corporate Governance Principle?. Advances in Social Science, Education and Humanities Research. Vol. 413, pp.71-77 (2019)

[14] Kurniasih, D, Israwan P, Setyoko \& Imron, M: Problems of Public Accountability in Village Government Business Management (Study on Village Business Enterprises in Banyumas, Indonesia), Journal of Public Administration and Governance, 7 (4), pp.147-164 (2017)

[15] Law No.9/2017 concerning Access to Financial Information for Taxation Purposes repeals several articles in several laws and Law No.17/2017 concerning General Election repeals several articles in 3 laws.

[16] Surono, A: Peranan Hukum dalam Pengelolaan Sumber Daya Alam Skala Desa oleh Badan Usaha Milik Desa (BUMDES) dalam Meningkatkan Kesejahteraan Masyarakat Desa. Jurnal Rechtsvinding. Vol.6, No.3. pp.459-478 (2017)

[17] Asyhadie, Z., \& Sutrisno, B: Hukum Perusahaan dan Kepailitan. Erlangga, Jakarta (2012)

[18] Sukarja, D., Siregar, M., \& Lubis, T.M.: Telaah Kritis Status Badan Hukum dan Konsep Dasar Badan Usaha Milik Desa. Arena Hukum. Vol.3, No.3. pp.568-588 (2020) hlm. 111-112. 